\title{
Application of Heterogeneous Robotic System for Underwater Oil Spill Scenario
}

\begin{abstract}
The tragic Deepwater Horizon accident in the Gulf of Mexico in 2010 as well as the increase in deepwater offshore activity have increased public interest in counter-measures available for subsurface releases of hydrocarbons. To arrive at proper contingency planning, response managers urge for a system for instant detection and characterization of accidental releases. Along these lines, this paper describes the application of a heterogeneous robotic system of unmanned vehicles: autonomous underwater vehicle (AUV), unmanned surface vehicle (USV) and unmanned aerial vehicle (UAV) extended with the oil spill numerical modeling, visualisation and decision support capabilities. A first set of field experiments simulating oil spill scenarios with Rhodamine WT was held in Croatia during the early autumn 2014. and the second set of experiments were held in Spain during the summer 2015. The objectives of this experiment were to test: effectiveness of the system for underwater detection of hydrocarbons, heterogeneous multi-vehicle collaborative navigation and communication as well as decision support system, visualisation of the system components and detected spill.
\end{abstract}

Keywords: unmanned vehicles, oil spill, heterogeneous fleet, decision support system

\section{Introduction}

Hydrocarbons and their derivatives comprise the largest energy source in the world. Exploration and extraction activities in the marine environment are expected to continue to grow, both at coastal and deep water sites. Therefore, it is very important to ensure effective prevention and response to oil spills. The tragic Deepwater Horizon accident in the Gulf of Mexico in 2010 as well as an increase in deepwater offshore activity have increased public interest in counter-measures available for sub-surface releases of hydrocarbons.

Available remote-sensing techniques are efficient and well-developed for surface disasters, but they are not useful for underwater releases. The most important information needed by response teams are: type of hydrocarbon, the scale, volume and position of release. In the scope of the project "Autonomous underwater vehicles ready for oil spill UReady4OS" [1] heterogeneous robotic fleet with Decision Support System is proposed 
to address the problem. The robotic system consists of heterogeneous unmanned vehicles: autonomous underwater vehicles (AUV), unmanned surface vehicles (USV) and unmanned aerial vehicles (UAV), while Decision Support System consists of an oil spill trajectory simulation model and a Command and Control Console.

The underwater vehicles with hydrocarbon sensor directly measure hydrocarbon concentration while unmanned surface and aerial vehicles sense the surface and serve as a communication link to make the collected data available to a remote ground station. Once the information reaches the ground station it is merged with other useful data sources such as output from numerical spill trajectory models, aerial photographs or hydrodynamic hind- and forecast and visualised in the Command and Control software. All these information layers actively assist in the overall system mission design in order to better capture the extent and intensity of the spill.

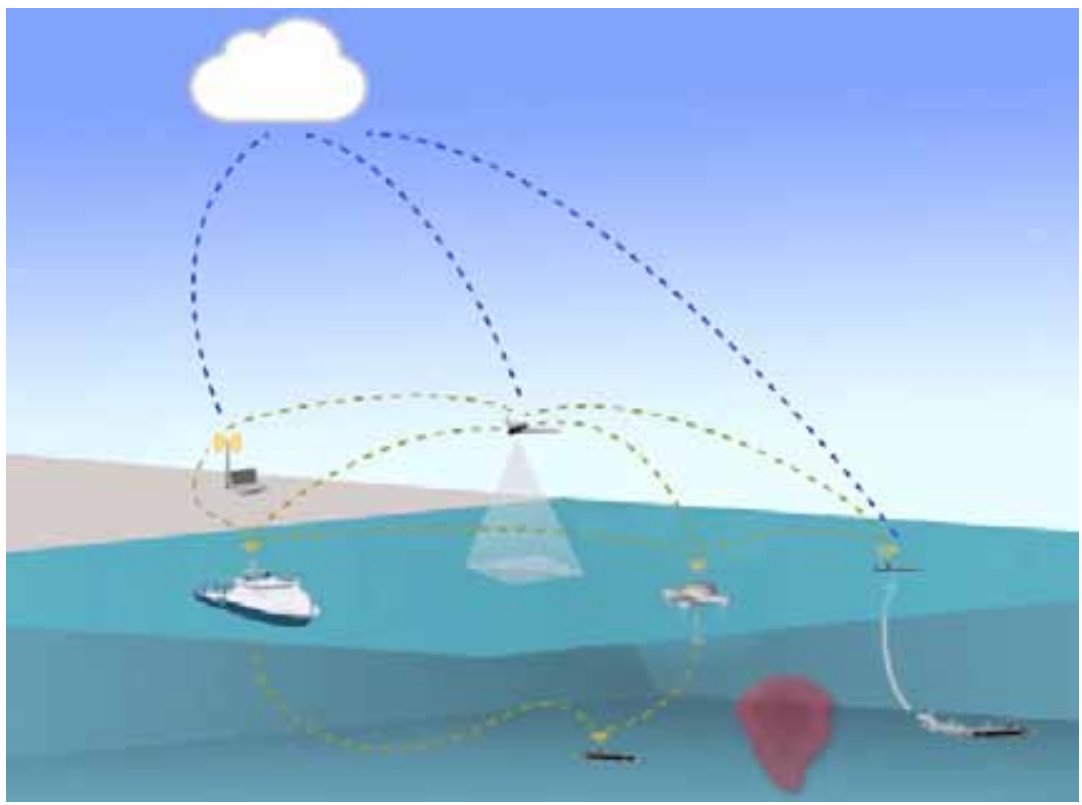

Figure 1. heterogeneous robotic system

\section{Material and methods}

Partners in the project "UReady4OS" are Technical University of Cartagena Spain, University of Porto Portugal, University of Zagreb Croatia and University of Cyprus, Cyprus.

Autonomous Underwater Vehicle is an untethered vehicle able to cover the large area, including the water column and accurately geo-reference measurements [2]. In order to model spatio-temporal distribution of the pollutant, hydrocarbon sensor is 
installed on an AUV. An AUV can perform pre-planned missions, generated according to available information prior to mission or adaptive mission, modified on-the-fly, based on real time concentration measurements. The goal of the adaptive mission is pre-set in order to achieve the mission objective such as to find the source, to monitor the plume (stay in the plume) or to find and monitor the plume boundaries. Two models of lightweight, one-man-portable AUVs [3] that can be easily launched, operated and recovered, were used during the experiments: LAUV and IVER2 vehicle (Fig. 2).

Selected hydrocarbon sensor was an in-situ submersible Turner Designs Cyclops 7 fluorometer [4]. Selection was based on specification, small size and weight. The sensor probe was installed in the nose of the vehicle, and connected to the main processing unit which processes and stores the data.

Unmanned Aerial Vehicle is a fast platform used to make an initial survey over a large surface area (Fig. 2). It is equipped with an Ethernet camera for real-time transmission to the base station or the camera with the better resolution for the offline analysis. The UAV also functions as a bridge, working as an Local Area Network access point between base station and the other systems deployed but out of range from the base station.

Unmanned Surface Vehicle is an autonomous robot equipped with payload for navigation, acoustic localisation and communication with the underwater agents and WiFi communication with an aerial agents or a ground station (Fig. 2) [5]. It serves as a surface sensing agent, real-time link with the AUVs as well as the operational space surface marker.

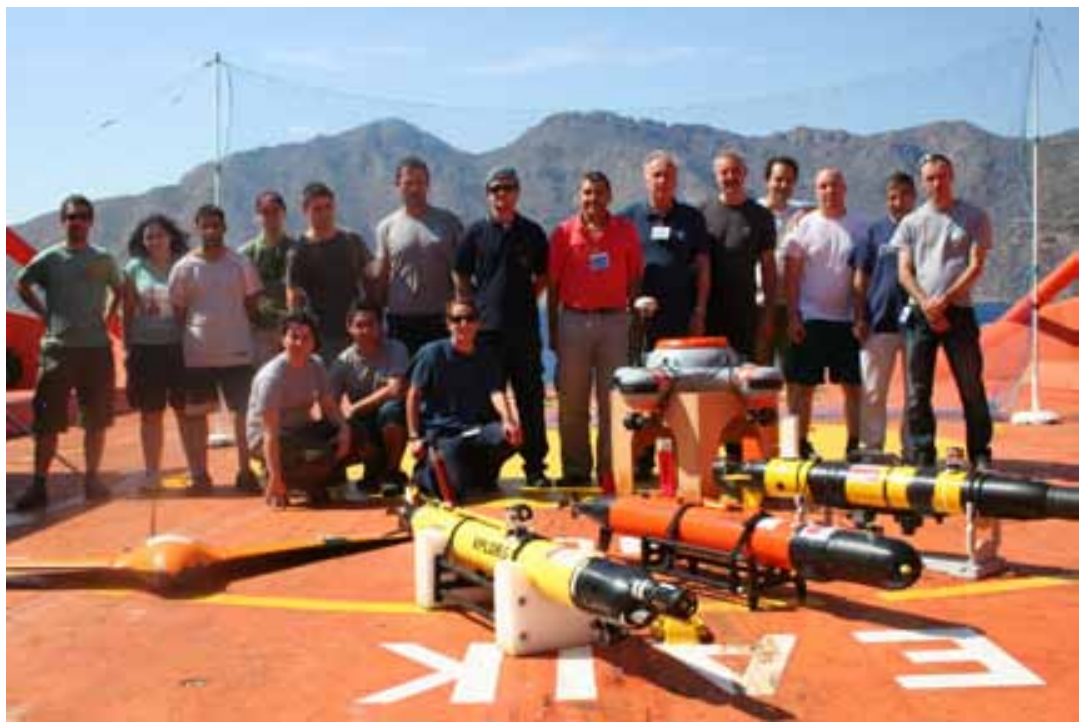

Figure 2. Cartagena 2015 experiments, Aerial, Surface and Underwater vehicles and participants 
Decision Support System consist of Command/Control and oil spill modelling software. A software package named Neptus [6] developed by University of Porto, is visualization console used to plan and review collected data and to provide full situational awareness in regard to the vehicles' state, as shown in Fig. 4. In what concerns the decision support, Neptus was extended to read pollutant dispersion model output. The temporal oil spill data is presented in the Neptus console as a georeferenced colour map showing the density of the oil (coloured grid of points) overlaid onto the operational space map. This data evolves over time and gives the operator information that is used for planning the surveys. Additionally, real-time collected data from the AUVs is also overlaid, feeding the operator with an updated picture of the actual spreading of oil. Oil spill modelling complements AUV operations in two ways. It provides quick initial estimate of expected spill trajectory using the available forecast data. The predicted fate assists in the initial mission planning of AUVs reducing the sampling area. Secondly, the information retrieved by the vehicles (oil concentration, water temperature and currents) feed the oil spill model to predict the fate of the observed plume, including its size and shape. The simulations are performed by MEDSLIK-II, an oil spill and trajectory 3D model [7].

\section{Experiments, results and discussion}

Two sets of experiments were held in the scope of the project. A first experiments were held in Croatia from 22nd of September to 2nd of October 2014 and the second, demonstration experiments were held in Spain from 22nd to 26st of June 2015. The oil spill was simulated with Rhodamine WT, a fluorescent non toxic and biodegradable chemical product commonly used to track flows. The results of the first experiments are summarized in the following conclusions.

An AUV with integrated fluorometer can be efficiently used for in-situ spatial detection and quantification of a pollutant of interest. Fig. 3. presents AUV entering the plume and concentration measurements. A few false positive readings were recorded when the fluorometer was exposed to the ambient light. 


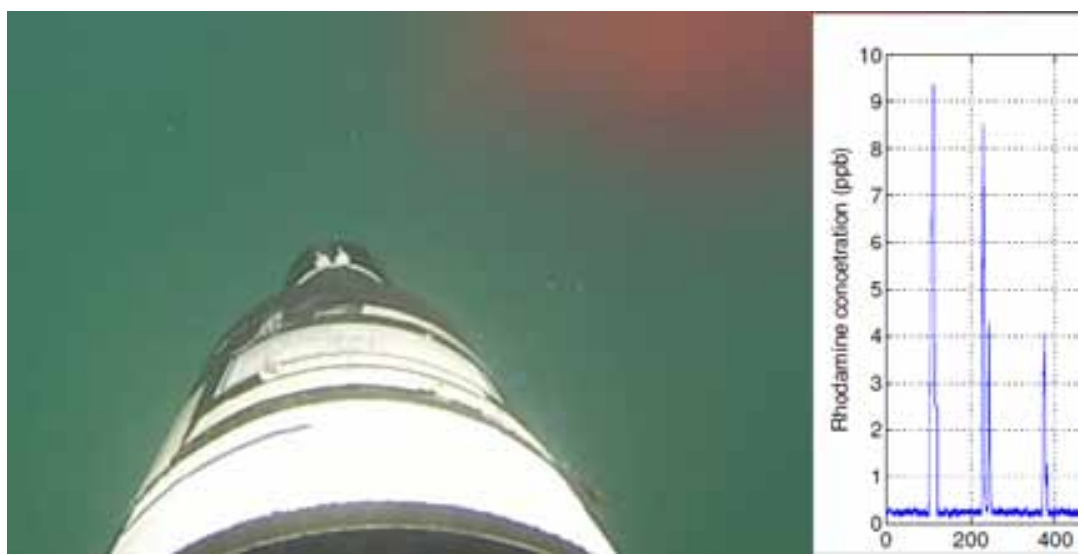

Figure 3. AUV in front of red Rhodamine plume, upper-right corner. On the right, Rhodamine concentration measurement

Multiple heterogeneous vehicles can efficiently operate together when adequate communication protocols for acoustic and WiFi communication are applied. The first multi-vehicle scenario involved AUVs scanning the water column and UAV performing the surface survey. Data, recorded on board the vehicle, become available at the base station, once the AUV is on the surface, via UAV which serves as a WiFi range extender. In the case that more than one AUV is used at a time, the size of the scanned area is proportionally increased but it makes the mission more complex and requires more logistic effort. The second scenario involved an AUV and an USV. Such a fleet was capable of transferring near-real-time oil-in-water concentration data to the mission base. An AUV continuously fed the USV with measurement data via acoustic link and USV forwarded geo-referenced concentration data to the base via WiFi.

The visualisation system with incorporated pollution numerical modelling has a potential to be valuable decision support tool. Fig. 4 presents the mission details in Neptus, our Visualisation and Decision Support System. The view shows fleet management information and spatial distribution of the pollution through the $2 \mathrm{D}$ overlay of the concentration measurements (colour-bar). All this information, available in near-real time, support decision making process shore-side. 


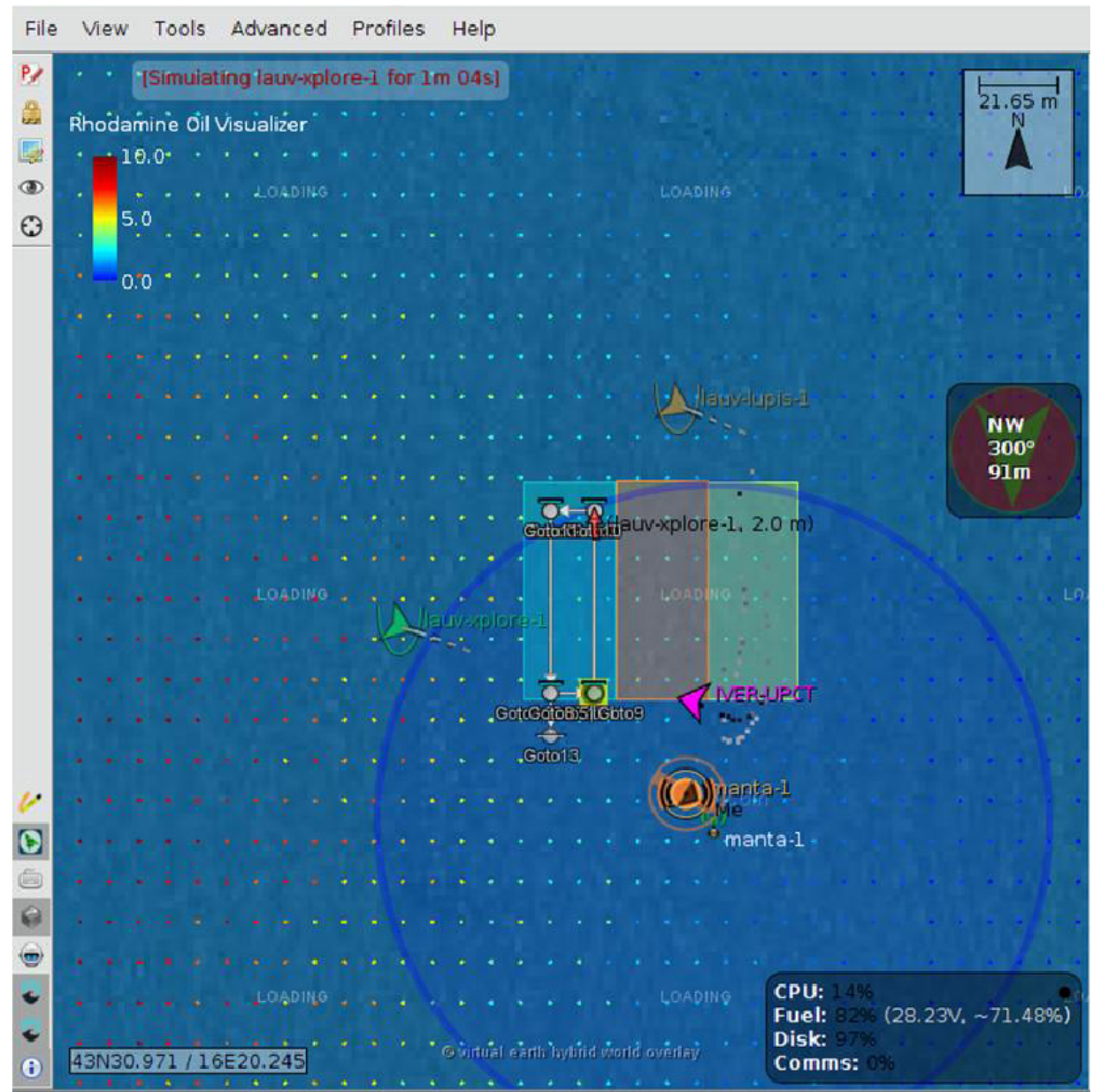

System: lauv-xplore-1 Plan: survey1

Figure 4. Neptus - Visualisation and Decision Support System.

The goal of the 2015 demonstration experiments was to test the fleet performance in envisioned, realistic spill situation. The experiments should have verified that a fleet of aerial, surface and underwater autonomous vehicles was able to identify, quantify and monitor a simulated oil spill made with Rhodamine WT, that decision support system provided and suitably presented information required by oil spill response team and that teams were able to handle all phases of the mission, from planning to the safe recovery and data analysis.

The team from University of Cyprus made numerical predictions of the pollutant cloud evolution, shown in Fig. 5., for optimal mission planning, performed using Neptus. 
Then fleet of five autonomous vehicles were deployed simultaneously with the common goal to cooperatively address a simulated oil spill situation. During the trials, apart from a regular pre-planned mission, adaptive mission based on real time concentration measurements was also tested.

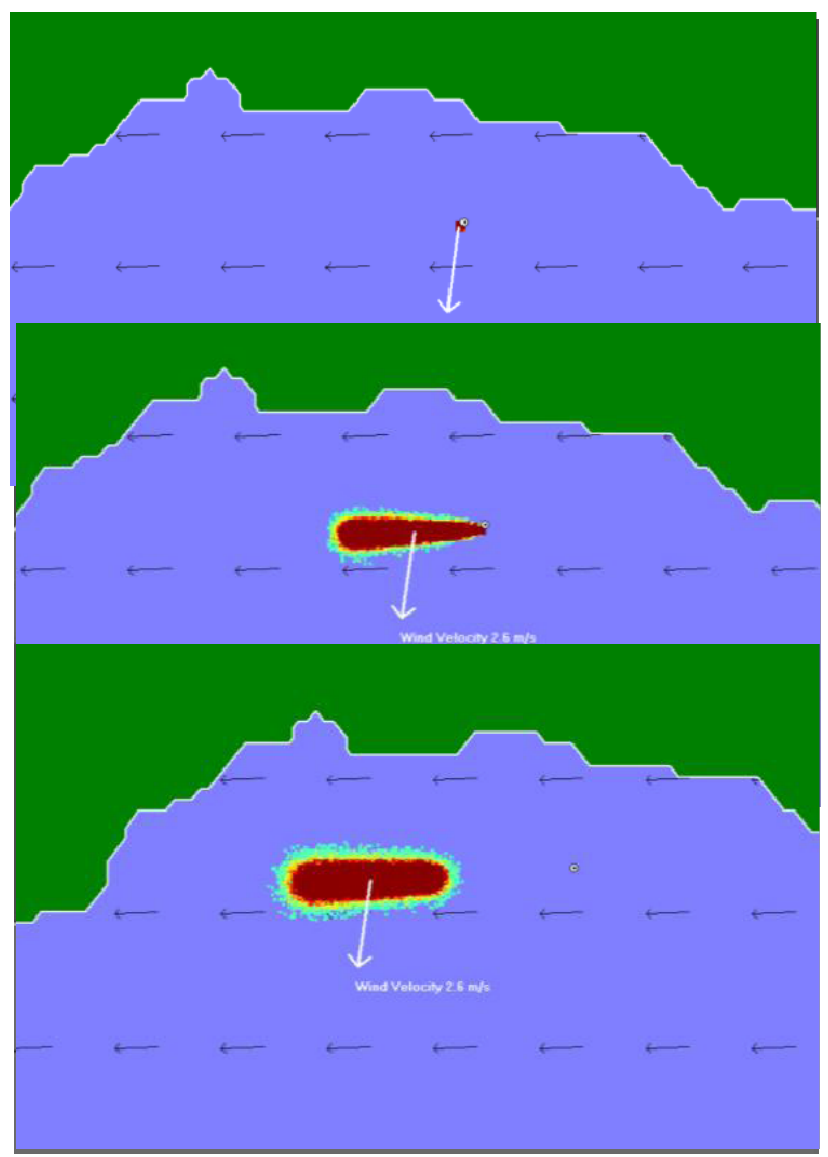

Figure 5. Modelling of the oil spill evolution (source: University of Cyprus)

Fig. 6 shows spatial pollutant concentration measurements from the fixed depth mission performed by the LAUV-LUPIS vehicle. The red circle indicates positive detection while the size of the circle represents the concentration measurement, bigger circle represents higher concentration.

Upper image shows AUV performing pre-planned straight transect until the moment of the first positive pollution detection. Circular Mission, initiated top side, replaced the initial lawn mower mission plan with the goal of mapping the area in the neighbourhood of the detected spill. 
Circular mission were performed a couple of times in the polluted area. The second image shows pollution concentration measurements during the second passage. Finally, field results fused with numerical model data and presented in Neptus demonstrated valuable contribution to the proper decision making process regarding the future actions.
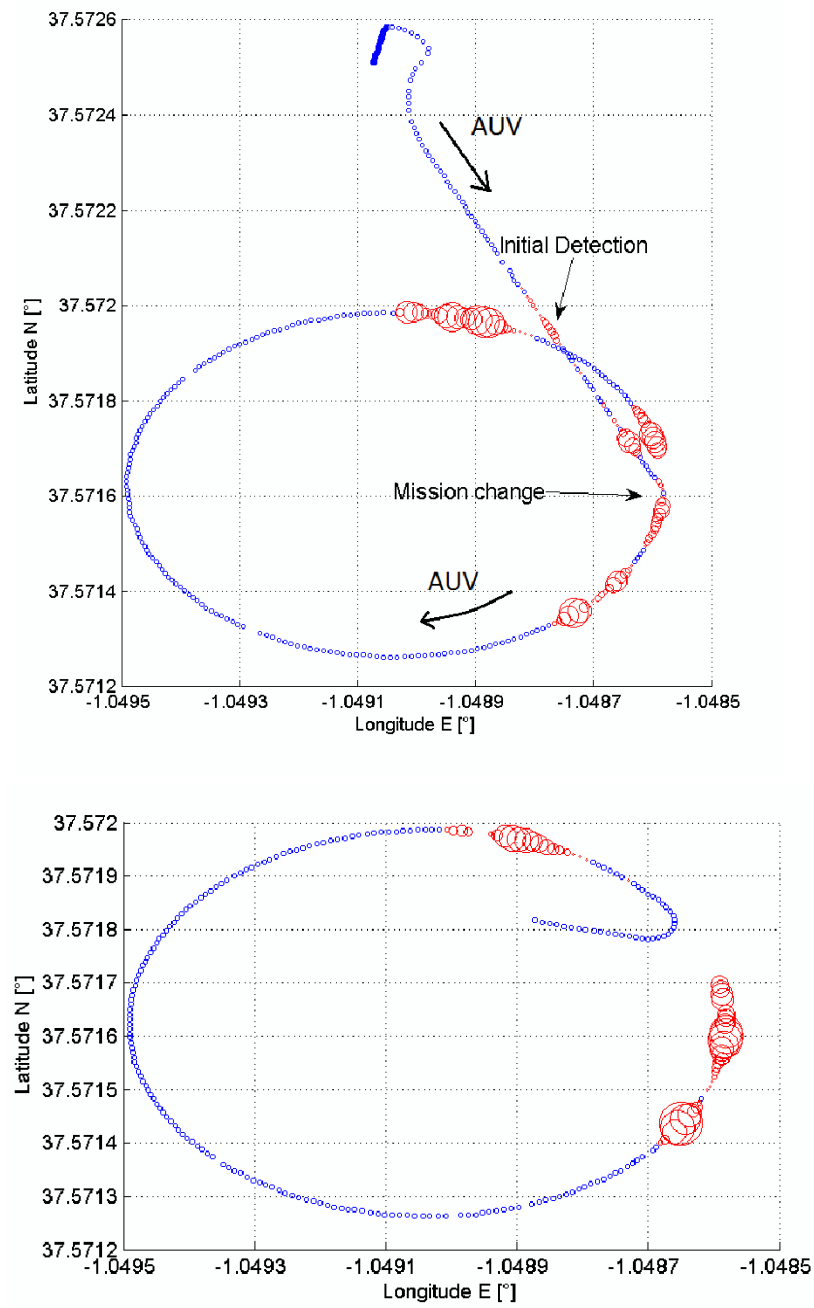

Figure 6. Spatial concentration measurement.

Red circle indicates positive detection of the pollution. The size of the circle is proportional to the concentration measurement. 


\section{Conclusions}

Project results showed that the flourometers integrated into an AUV, can be effectively used for in-situ measurement of pollutant concentrations in the water column. Incorporation of heterogenous robotic vehicles in the multi-agent fleet such as aerial and surface vehicle brought extra benefits such as: fast detection of the primary spill location, extended WiFi communication range of the AUVs and availability of the near-real-time concentration data for decision support and numerical modeling. The goals set out for the experiments were fulfilled: the team members involved, effectively coordinated and planned missions which were executed by the heterogeneous fleet in a near-real time scenario.

\section{Acknowledgements}

The work presented in this paper is performed in the framework of the European Commission DG-ECHO (Civil Protection) funded project "Autonomous underwater vehicles ready for oil spill - UReady4OS", Agreement Number ECHO/ SUB/2013/661056.

\section{References}

1. Web site of the project "Autonomous underwater vehicles ready for oil spill - UReady4OS", http:// www.upct.es/urready4os/?lang=en

2. Barišić M., Misković N., Vasilijević A., "Fusing Hydroacoustic Absolute Position Fixes with AUV On-Board Dead Reckoning”, Proceedings of the 10th IFAC Symposium on Robot Control, pp. 211-217, 2012.

3. Madureira L., Sousa A., Braga J., Calado P., Dias P., Martins R., Pinto J., Sousa J., "The light autonomous underwater vehicle: Evolutions and networking”, OCEANS - Bergen, 2013 MTS/ IEEE, pp. 1-6, June 2013.

4. Cyclops submersible sensors User's Manual, Turner Designs,Sunnyvale, CA, 2014. [Online]. Available: http://www.turnerdesigns.com/t2/doc/manuals/998-2100.pdf

5. Mišković, N., Nađ, Đ., Stilinović, N., Vukić, Z., "Guidance and control of an overactuated autonomous surface platform for diver tracking”, 21st Mediterranean Conference on Control and Automation, MED 2013 - Conference Proceedings, pp. 1280-1285, 2013. DOI: 10.1109/ MED.2013.6608884

6. Pinto J., Dias P., Martins R., Fortuna J., Marques E., Sousa J., “The LSTS toolchain for networked vehicle systems", OCEANS 2013 MTS/IEEE Bergen: The Challenges of the Northern Dimension, 2013.

7. Web site of the oil spill model "MEDSLIK-II", http://medslikii.bo.ingv.it/ 


\title{
Heterogeni robotski sustav za detekciju i mapiranje podvodnih naftnih mrlja
}

\begin{abstract}
Sažetak
Tragični "Deepwater Horizon" incident u Meksičkom zaljevu 2010 godine kao i znatno pojačana podmorska eksplatacija nafte u zadnje vrijeme potaknuli su zanimanje javnosti za mjere u suzbijanju podmorskih izlijeva nafte. Za adekvatno planiranje u kriznim situacijama takvog tipa, sustavi za brzu detekciju i kvalifikaciju hidrokarbonata su od posebne važnosti. Članak u tom kontekstu opisuje primjenu heterogenog bespilotnog robotskog sustava i sustava za potporu odlučivanju. Heterogeni robotski sustav sastoji se od: autonomnog podvodnog vozila (AUV), bespilotnog površinskog vozila (USV) i bespilotne letjelice (UAV). Cijelokupan sustav ima još i mogućnosti numeričkog modeliranja naftnih mrlja, sustava za vizualizaciju i potporu odlučivanju. Eksperimenti na moru su održani u dva navrata, u jesen 2014 u Splitu u Hrvatskoj i ljeto 2015 u Cartageni u Španjolskoj. Naftna mrlja je simulirana sa bezopasnim Rodaminom WT. Cilj exksperimenata je bio ispitati učinkovitost i pouzdanost podvodne detekcije hidrokarbonata, navigacija i komunikaciju robotskog sustava i vrijednost sustava za potporu odlučivanju.
\end{abstract}

Ključne riječi: bespilotna vozila, zagađenje naftom, heterogena flota, sustav za potporu odlučivanju 